\title{
EFEKTIFITAS BELAJAR ANAK SEKOLAH DASAR DENGAN BIMBINGAN ORANG TUA SELAMA PANDEMI COVID-19
}

\author{
Bayu Purbha Sakti ${ }^{1 *}$, Gunawan Budi ${ }^{2}$, Farida ${ }^{3}$ \\ 1,2,3 Universitas Widya Dharma Klaten \\ *Corresponding Author: $\otimes$ bayups@unwidha.ac.id
}

\begin{tabular}{l} 
Info Artikel \\
\hline Sejarah Artikel: \\
Diterima: $13 / 12 / 2021$ \\
Direvisi : $21 / 12 / 2021$ \\
Disetujui: $25 / 12 / 2021$ \\
\hline Keywords: \\
Elementary school \\
children, Parental \\
guidance, Internet signal \\
quality \\
\hline
\end{tabular}

Kata Kunci:

Anak sekolah dasar,

Bimbingan orang tua,

Kualitas sinyal internet

\begin{abstract}
Children's attitudes and parental guidance in dealing with online learning during this pandemic will determine the success of learning activities in elementary schools. This type of research is a qualitative research. This research is a qualitative research. The approach used leads to the phenomenon of online learning activities. Three students and 3 parents of class 3 SDN 3 Ketandan Klaten were used as research subjects. Observations were made to determine the process of online learning activities. Interviews were conducted to determine parental guidance and attitudes of elementary school children who undergo online learning activities. Documentation was conducted to determine the learning outcomes experienced by elementary school children. The data analysis technique used is data reduction, presentation, and verification. The results of the study were written related to the events experienced by parents and students. Learning activities for elementary school children who receive parental guidance during the Covid19 pandemic are influenced by several things. Things that affect the effectiveness of the learning mentioned above include the ability of parents in information technology, cellphones and whatsapp used in learning, the quality of internet signals provided by telecommunication services, the ability of children to understand learning materials and the involvement of parents accompanying children..
\end{abstract}

\begin{abstract}
Abstrak. Sikap anak dan bimbingan orang tua dalam menghadapi pembelajaran daring pada masa pandemi ini akan menentukan kesuksesan kegiatan pembelajaran di sekolah dasar. Jenis penelitian yang dilakukan merupakan penelitian kualitatif. Penelitian ini adalah penelitian kualitatif. Pendekatan yang digunakan mengarah pada fenomena kegiatan pembelajaran daring. Tiga siswa dan 3 orang tua kelas 3 SDN 3 Ketandan Klaten digunakan sebagai subyek penelitian. Observasi dilakukan untuk mengetahui proses kegiatan pembelajaran daring. Wawancara dilakukan untuk mengetahui bimbingan orang tua dan sikap anak sekolah dasar yang menjalani kegiatan pembelajaran daring. Dokumentasi dilakukan untuk mengetahui hasil belajar yang dialami anak sekolah dasar. Teknik analisis data yang digunakan adalah reduksi, penyajian, dan verifikasi data. Hasil penelitian ditulis berkaitan dengan kejadian yang dialami orang tua dan siswa. Kegiatan pembelajaran anak sekolah dasar yang mendapatkan bimbingan orang tua selama masa pandemi Covid-19 dipengaruhi beberapa hal. Hal-hal yang mempengaruhi kefektifan pembelajaran tersebut di atas antara lain, kemampuan orang tua dalam teknologi informasi, handphone dan whatsapp yang digunakan dalam belajar, kualitas sinyal internet yang disediakan jasa telekomunikasi, kemampuan anak memahami materi belajar serta keterlibatan orang tua mendampingi anak.
\end{abstract} How to Cite: Sakti, B. P., Budi, G., \& Farida, F. (2022). EFEKTIFITAS BELAJAR ANAK SEKOLAH DASAR DENGAN
BIMBINGAN ORANG TUA SELAMA PANDEMI COVID-19. Prima Magistra: Jurnal Ilmiah Kependidikan, 3(1), 92-99. https://doi.org/10.37478/jpm.v3i1.1409

Alamat korespondensi:

Jln.Ki Hajar Dewantoro Klaten Utara, Kabupaten Klaten, Jawa Tengah. @ bayups@unwidha.ac.id

\section{Penerbit:}

Program Studi PGSD Universitas Flores. (\$) primagistrauniflor@gmail.com 


\section{PENDAHULUAN}

Belajar yang dilakukan siswa pada masa pandemi Covid-19 adalah hal baru bagi siswa, guru, dan orang tua. Hal tersebut memunculkan gagasan bagi peneliti untuk mendalami masalah tersebut.

Pembelajaran daring telah memberikan kontribusi baru bagi dunia pendidikan. Kegiatan belajar yang dilakukan siswa secara daring telah menyebabkan gap atau pemisah dengan kegiatan belajar sebelumnya. Pengajaran yang dilakukan guru juga berbeda apalagi orang tua harus membimbing anaknya juga di rumahnya.

Kegiatan pembelajaran daring dilakukan menggunakan bantuan sinyal internet. Sejumlah pelajar memaksakan belajar di tepi aliran Sungai Kinal Kecamatan Kinal Kabupaten Kaur Bengkulu untuk mendapatkan sinyal internet (Nursalikah, 2021). Hal tersebut bisa menjadi masalah apabila siswa berada di tempat yang susah mendapatkan sinyal internet. Pembelajaran daring sangat bergantung dengan koneksi jaringan internet yang menghubungkan perangkat media guru dan siswa (Sakti \& Ayu, 2021). Kegiatan pembelajaran daring juga membutuhkan perangkat komputer atau smartphone yang lebih layak. Apabila dari beberapa hal tersebut di atas tidak mendukung maka kegiatan pembelajaran daring yang dilakukan siswa atau guru akan menjadi sulit. Oleh karena itu siswa dan guru harus bisa menggunakan internet. Penggunaan internet tentu saja dioperasikan dengan media komputer. Guru yang bekerja di zaman sekarang harus bisa menggunakan komputer yang berbasis internet (Sakti, 2021a).

Total kasus Covid-19 yang ditemukan di Indonesia sejak Maret 2020 hingga hari ini menjadi 3.718.821 kasus (Haf, 2021). Pemerintah di Indonesia memiliki kebijakan untuk menghentikan laju penyebaran Covid-19 dalam dunia pendidikan. Guru harus bersedia diuji kesehatannya yang berkaitan dengan Covid-19 (Sakti, 2021c). Salah satu kebijakan yang diterapkan pemerintah adalah pembelajaran daring. Pembelajaran daring juga dinamakan pembelajaran jarak jauh (Sakti, 2021b). Pembelajaran daring digunakan untuk mengalihkan pembelajaran tatap muka yang dilakukan di sekolah. Kegiatan pembelajaran ini dapat dilakukan di rumah siswa masingmasing.

Kegiatan pembelajaran daring yang dilakukan siswa tentu saja dibantu orang tua. Orang tua yang tidak memahami tentang sistem internet akan mengalami kesulitan. 10,2 persen masyarakat tidak tahu cara menggunakan internet di Indonesia (Septalisma, 2021). Orang tua sebagai bagian dari masyarakat akan dihadapkan pada penggunaan hal-hal yang berkaitan dengan internet. Orang tua yang tidak memahami tentang komputer atau smartphone akan mengalami kesulitan. Latar belakang pendidikan orangtua juga akan mempengaruhi mudah atau sulitnya pelaksanan kegiatan pembelajaran daring.

Kesulitan belajar dapat dialami anak sekolah dasar pada masa pandemi ini. Anak kelas 3 yang bersekolah di Malinau kesulitan membaca dan kurang semangat dalam belajar (Taufiq, 2021). Peran dan upaya orang tua sangatlah dibutuhkan dalam membimbing anak belajar. Hasil belajar siswa akan menjadi bermasalah jika siswa tidak melakukan perubahan yang lebih baik dari pengalaman yang dialaminya (Sakti, 2020a). Sikap anak dan orang tua dalam menghadapi pembelajaran daring pada masa pandemi ini akan menentukan kesuksesan kegiatan pembelajaran di sekolah dasar. Oleh karena itu, penulis ingin meneliti tentang efektivitas pembelajaran anak usia sekolah dasar yang dibimbing orang tua selama masa pandemi Covid-19.

Efektivitas pembelajaran adalah prilaku mengajar yang efektif ditunjukan oleh pendidik yang mampu memberikan pengalaman baru melalui pendekatan dan strategi khusus untuk mencapai tujuan pembelajaran (Fathurrahman et al., 2019). Seorang pendidik harus mempersiapkan kegiatan pembelajaran supaya dapat berjalan dengan efektif. Efektivitas pembelajaran memiliki empat indikator yaitu indikator input, process, output, dan outcome (Mulyasa, 2010). Beberapa hal yang menjadi bagian dari indikator input adalah karakteristik guru, fasilitas dan perlengkapan untuk mendukung berlangsungnya proses belajar mengajar. 
Beberapa hal yang menjadi bagian dari indikator process adalah perilaku guru, administratif guru, alokasi waktu guru, dan alokasi waktu siswa. Beberapa hal yang menjadi bagian dari indikator output adalah hasil yang berhubungan dengan perubahan sikap dan prestasi belajar. Beberapa hal yang menjadi bagian dari indikator outcome adalah jumlah lulusan ke tingkat pendidikan berikutnya dan prestasi belajar di sekolah yang lebih tinggi. Efektif atau tidaknya pembelajaran bisa dilihat dari aktivitas siswa selama pembelajaran berlangsung, respon siswa terhadap pembelajaran dan penguasaan materi tiap siswa (Yulianto \& Nugraheni, 2021). Kegiatan pembelajaran yang dilakukan pada masa pandemi Covid-19 akan mempengaruhi keempat indikator efektivitas pembelajaran.

Anak akan mulai berinteraksi dengan teman sebaya dan orang dewasa lainnya pada proses pembelajaran di sekolah dasar (Marsari et al., 2021). Namun pembelajaran daring telah membuat interaksi anak sekolah dasar berubah. Hal tersebut akan membuat cara berpikirnya menjadi berubah juga. Cara berpikir anak usia sekolah dasar berbeda dengan anak pra sekolah dan orang dewasa (Khaulani et al., 2020). Perubahan interaksi dan cara berpikir anak sekolah dasar harus diketahui guru dan orang tua. Bimbingan yang dilakukan oleh orangtua adalah sebagai petunjuk atau penuntun cara melakukan sesuatu hal dengan baik dan benar kepada anaknya (Novita \& Agustina, 2018). Orang tua yang giat membimbing akan menghasilkan anak yang lebih baik dalam belajar. Bimbingan orang tua antara lain memberikan kasih sayang, memenuhi kebutuhan anaknya, menyediakan fasilitas belajar, memberikan motivasi dan menciptakan suasana belajar yang kondusif (Ramopoly et al., 2020). Hasil dari bimbingan tersebut diharapkan dapat digunakan untuk menghadapi pembelajaran daring dalam masa pendemi Covid-19. Para orang tua memiliki peran menjadikan anak yang memiliki kepribadian baik atau buruk (Sakti, 2020b). Oleh karena itu, bimbingan dari orang tua yang dilakukan untuk anaknya dalam belajar akan menentukan hasil belajar dalam masa pandemi Covid-19.
Pandemi Covid-19 membawa banyak perubahan bagi masyarakat (Ridlo, 2020). Salah satu perubahan yang dialami masyarakat berasal dari kebijakan Pemerintah Indonesia. Pemerintah Indonesia mengeluarkan kebijakan larangan orang untuk berkumpul dan beraktivitas di luar rumah serta bekerja dan belajar dari rumah terkait pandemi Covid-1 9 (Amalia \& Sa'adah, 2021). Anak sekolah dasar diharapkan belajar dari rumah sesuai anjuran dari Pemerintah Indonesia. Sistem belajar yang digunakan anak tersebut tidak dilakukan secara tatap muka langsung dengan guru. Pandemi Covid-19 saat ini menjadikan berubahnya sistem belajar mengajar dimana pada setiap harinya melaksanakan tatap muka berganti menjadi pembelajaran secara daring (Yulianto \& Nugraheni, 2021). Kegiatan pembelajaran daring harus dilakukan dengan menggunakan media pembelajaran. Proses pembelajaran akan lebih mudah ketika menggunakan media yang sesuai pada masa Covid-19 (Maulana, 2021). Penggunaan handphone sebagai akan memudahkan Kegiatan pembelajaran daring. Penggunaan handphone juga akan mempengaruhi kegiatan yang dilakukan anak sekolah dasar.

Tujuan dari penelitian ini adalah untuk mengetahui hal-hal yang mempengaruhi efektivitas belajar anak sekolah dasar dengan biimbingan orang tua selama masa pandemi Covid-19. Informasi tentang belajar anak sekolah dasar dan bimbingan orang tua semoga dapat menambah pengetahuan dalam dunia pendidikan terutama pada masa pandemi ini. Kegiatan belajar yang dialami anak sekolah dasar tentu saja berbeda dengan pada masa sebelum pandemi. Oleh karena itu penulis ingin meneliti fenomena ini.

\section{METODE PENELITIAN}

Penelitian ini adalah penelitian kualitatif. Pendekatan yang digunakan mengarah pada fenomena kegiatan pembelajaran daring. Tiga siswa dan 3 orang tua kelas 3 SDN 3 Ketandan Klaten digunakan sebagai subyek penelitian. Teknik pengumpulan data yang digunakan adalah teknik observasi, wawancara, dan dokumentasi. Data penelitian yang dikumpulkan adalah hasil pengumpulan data dari siswa dan orang tua. Observasi dilakukan 
terhadap siswa untuk mengetahui proses kegiatan pembelajaran daring. Wawancara dilakukan terhadap orang tua untuk mengetahui bimbingan orang tua dan sikap anak sekolah dasar yang menjalani kegiatan pembelajaran daring. Dokumentasi dilakukan terhadap siswa untuk mengetahui hasil belajar yang dialami anak sekolah dasar. Teknik analisis data yang digunakan adalah reduksi, penyajian, dan verifikasi data. Data penelitian ini dikurangi karena tidak semua bukti lampiran ditulis di hasil penelitian. Hasil penelitian ditulis berkaitan dengan kejadian yang dialami orang tua dan siswa.

\section{HASIL DAN PEMBAHASAN}

\section{Hasil}

Hasil penelitian yang didapatkan yaitu berkaitan dengan indikator dari efektivitas pembelajaran. Beberapa indikator yang diteliti adalah indikator input, process, dan output. Indikator outcome tidak diteliti karena indikator ini tidak digunakan di kelas tiga. Penjelasan mengenai hasil penelitian kegiatan pembelajaran daring selama masa pandemi Covid-19 di SDN 3 Ketandan Klaten adalah sebagai berikut:

\section{Penjelasan mengenai hasil indikator input}

Menurut Ibu I, penggunaan teknologi dalam pembelajaran daring di sekolah yang diampunya sekarang ini menggunakan handphone dengan aplikasi whatsapp group. Kegiatan pembelajaran dilakukan menggunakan voice note dan juga video di dalam whatsapp group. Proses kegiatan pembelajaran dilakukan dengan mencari buku pedoman dan mencari solusi atas kesulitan yang dihadapi anaknya saat menghadapi pembelajaran daring melalui whatsapp group di handphone. Menurut Ibu II, menyimpulkan bahwa tingkat kemampuan orang tua dalam memanfaatkan teknologi informasi dan komunikasi tidak terlalu baik. Hal ini disebabkan orang tua tidak terbiasa menggunakan handphone untuk mendampingi proses pembelajaran siswa. Selain itu, kesulitan jaringan internet juga semakin menghambat proses pembelajaran yang dilakukan siswa menggunakan proses daring. Beliau, selalu berusaha untuk mendukung pembelajaran anak didiknya dengan cara memberi dukungan moral terhadap anak agar tidak down saat mengalami kesulitan. Menurut Ibu III, menyimpulkan bahwa tingkat kemampuan orang tua dalam memanfaatkan teknologi informasi dan komunikasi cukup baik. Orang tua memahami mekanisme pembelajaran yang dilakukan sekolah. Beliau dalam mengatasi kesulitan anak saat proses pembelajaran daring dengan mengawasi dan mendampingi anak saat pembelajaran daring di rumah. Bagi beliau, cara ini sangat baik untuk mengatasi kesulitan anak di rumah.

Menurut siswa I, siswa tersebut menyimpulkan bahwa meskipun orang tua kurang memahami cara mendampingi siswa saat proses pembelajaran, orang tua selalu menanyakan kesulitan belajar setiap sore hari dan meminta anak untuk mengulangi pembelajaran tersebut. Menurut siswa II dan III, tingkat kemampuan orang tuanya dalam memanfaatkan teknologi informasi dan komunikasi cukup baik. Menurut siswa yaitu I, II, \& III, siswa/siswi tersebut menyimpulkan bahwa mereka menguasai teknologi dalam melakukan kegiatan pembelajaran daring seperti membuka handphone bahkan mencaricari informasi sendiri.

Menurut Ibu I, fasilitas belajar yang dimiliki kurang mendukung, karena keterbatasan fasilitas buku dan handphone yang dimiliki. Ibu II, menyimpulkan jika anaknya telah belajar menggunakan handphone orang tua. Anak harus bergantian menggunakan alat komunikasi tersebut dengan orang tua. Menurut Ibu III, menyimpulkan bahwa fasilitas pendukung pembelajaran anak sudah dipenuhi semua, sehingga tidak menimbulkan hambatan-hambatan pada proses pembelajaran.

\section{Penjelasan mengenai hasil indikator process}

Menurut Ibu I, hambatan terbesar dalam proses pembelajaran daring adalah jaringan/sinyal. Beliau menjelaskan saat siswa harus mengerjakan tugas yang diberikan oleh sekolah, biasanya pada jam tersebut juga kualitas sinyal yang dihasilkan juga menurun. Menurut Ibu II dan III, menyimpulkan bahwa permasalahan kualitas sinyal merupakan faktor terbesar penghambat siswa, selain sarana lain seperti alat komunikasi yang terbatas. 
Menurut siswa I dan III, alokasi waktu siswa dalam pembelajaran daring sudah sesuai arahan yang diberikan oleh sekolah/guru. Menurut siswa II, jadwal yang telah disepakati diawal dapat memberikan keleluasaan siswa untuk dapat beristirahat di siang hari sehingga kesehatan siswa juga terjaga. Menurut siswa I, II, dan III, siswa/siswi tersebut menyimpulkan bahwa sistem pembelajaran yang diberikan sekolah adalah mengikuti arahan guru dari setiap materi yang diberikan guru melalui whatsapp.

Menurut Ibu I dan II, menyimpulkan bahwa orang tua harus terlibat, bahkan orang tua juga ikut dalam mencari informasi atau materi di google. Hal ini penting dilakukan untuk meringankan beban dan rasa kebosanan anak di rumah. Menurut Ibu III, menyimpulkan bahwa beliau melakukan pengawasan dan mendampingi anak saat pembelajaran daring di rumah dan menyediakan handphone.

3. Penjelasan mengenai hasil indikator output

Menurut Ibu I, sikap anak saat proses pembelajaran daring adalah kurang mampu memahami materi pembelajaran yang di berikan dari pihak sekolah melalui daring, batas waktu yang terbatas, sehingga menimbulkan tidak terselesainya materi dan soal pembelajaran daring. Menurut Ibu II dan III, menyimpulkan bahwa anak tidak menjadi maksimal dalam memperoleh hasil belajar.

Menurut Ibu I, II, dan III, hambatanhambatan yang muncul seperti kualitas sinyal dimana tidak mampu dikontrol oleh kemampuan siswa mempengaruhi hasil belajar anak dalam menjalankan pembelajaran daring. Menurut siswa I, II, dan III, hasil pekerjaan agak lama bisa terkirim dan diunggah di whatsapp.

\section{Pembahasan}

Hasil pembahasan mengenai efektivitas pembelajaran daring anak usia sekolah dasar yang dibimbing orang tua selama masa pandemi Covid-19 mengarah pada anak, orang tua, handphone, whatsapp, dan internet. Pembelajaran daring telah dilaksanakan di sekolah dasar. Pembelajaran daring ini diharapkan sebagai sarana yang efektif guna melaksanakan pembelajaran di masa pandemi Covid-19 (Utomo et al., 2021). Pembelajaran daring yang dilakukan anak sekolah dasar harus diawasi oleh guru dan orang tua mereka.

Kemampuan orang tua dalam teknologi informasi mempengaruhi keefektifan pembelajaran. Orang tua sebaiknya mampu untuk mengembangkan kemampuan literasi digitalnya supaya orang tua dapat menggunakan alat digital dengan berbagai fitur kemajuan seiring perkembangan zaman (Ain et al., 2021). Orang tua harus membiasakan dalam menggunakan alat digital supaya lebih mahir dalam menghadapi pembelajaran daring. Orang tua yang mahir dan terlibat dalam kegiatan pembelajaran daring tentunya sangat diharapkan anak. Keterlibatan orang tua mendampingi anak mempengaruhi keefektifan pembelajaran. Adanya perhatian dari orang tua dapat memotivasi anak belajar dengan sungguh-sungguh sehingga hasil yang diperoleh dari kegiatan belajar juga maksimal (Fatmala et al., 2021). Perhatian dan motivasi anak diharapkan dapat menunjang kegiatan pembelajaran yang lebih efektif.

Handphone dan whatsapp yang digunakan dalam belajar mempengaruhi keefektifan pembelajaran. Handphone dapat digunakan untuk mencari sumber informasi untuk pelajaran melalui aplikasi google (Deby et al., 2021). Handphone juga memiliki aplikasi whatsapp. Aplikasi whatsapp memiliki beberapa fitur diantaranya adalah fitur berkirim pesan, berbagi gambar atau video, dan berbagi dokumen hingga melakukan video call dengan siswa (Bhagaskara et al., 2021). Penggunaan media whatsapp dapat digunakan untuk kelancaran serta meningkatkan hasil belajar siswa meskipun dengan suasana daring maupun keterbatasan keadaan masing-masing siswa (Eryani \& Febrianto, 2021).

Kemampuan anak memahami materi belajar mempengaruhi keefektifan pembelajaran. Keefektifan pembelajaran dapat dicermati dari aktivitas selama proses belajar mengajar seperti respon dan kemampuan penguasaan teori oleh siswa (Irmada \& Yatri, 2021). Anak dapat belajar dengan efektif jika anak dibimbing dan diarahkan oleh orang tua. Orang tua dan anak juga harus mencermati sinyal internet yang digunakan pada 
handphone. Kualitas sinyal internet yang disediakan jasa telekomunikasi mempengaruhi keefektifan pembelajaran. Kualitas sinyal internet yang buruk karena adanya penghalang yang memiliki bangunan yang cukup padat sehingga menghambat pemancaran dari BTS (Hakim et al., 2021). Kualitas internet juga dipengaruhi dari jenis handphone yang digunakan.

\section{SIMPULAN DAN SARAN}

Keefektifan pembelajaran daring anak sekolah dasar yang dibimbing orang tua selama masa pandemi Covid-19 dipengaruhi beberapa hal. Hal-hal yang mempengaruhi kefektifan pembelajaran tersebut di atas antara lain, kemampuan orang tua dalam teknologi informasi, handphone dan whatsapp yang digunakan dalam belajar, kualitas sinyal internet yang disediakan jasa telekomunikasi, kemampuan anak memahami materi belajar serta keterlibatan orang tua mendampingi anak.

\section{DAFTAR PUSTAKA}

Ain, N., Novianti, R., Solfiah, Y., \& Puspitasari, E. (2021). Analisis Kemampuan Literasi Digital Orang Tua Anak Usia Dini di Kecamatan Tampan Kota Pekanbaru Riau. Lectura: Jurnal Pendidikan, 12(1), 70-85. https://doi.org/10.31849/LECTURA.V1 2I1.6073

Amalia, A., \& Sa'adah, N. (2021). Dampak Wabah Covid-19 Terhadap Kegiatan Belajar Mengajar Di Indonesia. Jurnal Psikologi, 13(2), 214-225. https://doi.org/10.35760/PSI.2020.V13I 2.3572

Bhagaskara, A. E., Afifah, E. N., \& Putra, E. M. (2021). Pembelajaran dalam Jaringan (DARING) Berbasis WhatsApp di SD Yapita. ZAHRA: Research and Tought Elementary School of Islam Journal, 2(1), 13-23. https://doi.org/10.37812/ZAHRA.V2I1. 183

Deby, D., Offeny, O., \& Saefulloh, A. (2021). Dampak Penggunaan Handphone Dalam Pembelajaran Pkn Pada Masa Pandemi Covid-19 Terhadap Siswa
Kelas XI Di SMAN 3 Palangka Raya. Jurnal Ilmu Pendidikan Ahlussunnah. http://www.ojs.stkipahlussunnah.ac.id/index.php/jipa/article/ view/143

Eryani, \& Febrianto. (2021). Efektivitas Penggunaan Media Whatsapp Dalam Pembelajaran Akuntansi Di Masa Pandemi Covid-19. Jurnal Pendidikan Ekonomi Akuntansi Kewirausahaan. https://ojs.unpkediri.ac.id/index.php/jpe aku/article/view/16286

Fathurrahman, A., Sumardi, S., Yusuf, A. E., \& Harijanto, S. (2019). Peningkatan Efektivtas Pembelajaran Melalui Peningkatan Kompetensi Pedagogik Dan Teamwork. Jurnal Manajemen Pendidikan, $\quad 7(2), \quad 843-850$. https://doi.org/10.33751/JMP.V7I2.1334

Fatmala, S., Bintoro, H. S., \& Ardianti, S. D. (2021). Analisis Perhatian Orang Tua Selama Pembelajaran Daring Terhadap Kemampuan Pemahaman Matematis Siswa. Jurnal Ilmiah Bina Edukasi, 14(1), 01-10. https://doi.org/10.33557/JEDUKASI.V1 4I1.1365

Haf, H. (2021). Positif Corona di RI 10 Agustus Tambah 32.081, Kematian 2.048. https://news.detik.com/berita/d5677259/positif-corona-di-ri-10agustus-tambah-32081-kematian-2048

Hakim, A. R., Tjahjamooniarsih, N., \& Suryadi, D. (2021). Analisis Kualitas Jaringan Internet Dengan Sinyal 4G LTE Dengan Metode QOS. Jurnal Teknik Elektro Universitas Tanjungpura, 2(1). https://jurnal.untan.ac.id/index.php/jteun tan/article/view/48187

Irmada, F., \& Yatri, I. (2021). Keefektifan Pembelajaran Online Melalui Zoom Meeting di Masa Pandemi bagi Mahasiswa. Jurnal Basicedu, 5(4), 2423-2429.

https://doi.org/10.31004/BASICEDU.V 5I4.1245

Khaulani, F., S, N., \& Irdamurni, I. (2020). Fase Dan Tugas Perkembangan Anak 
Sekolah Dasar. Jurnal Ilmiah Pendidikan Dasar, 7(1), 51-59. https://doi.org/10.30659/PENDAS.7.1.5 $1-59$

Marsari, H., Neviyarni, N., \& Irdamurni, I. (2021). Perkembangan Emosi Anak Usia Sekolah Dasar. Jurnal Pendidikan Tambusai, 5(1), 1816-1822. https://jptam.org/index.php/jptam/article /view/1182

Maulana, M. A. (2021). Efektivitas Pembelajaran Daring Terhadap Hasil Belajar Biologi Pada Konsep Biodiversitas Di Kelas X IPA MA Muhammadiyah Salaka Kabupaten Takalar. Jurnal Riset Dan Inovasi Pembelajaran, 1(1), 85-95. https://doi.org/10.51574/JRIP.V1I1.22

Mulyasa, M. (2010). Menjadi Guru Profesional. Remaja Rosdakarya. Google Scholar

Novita, L., \& Agustina, A. (2018). Bimbingan Orang Tua Dengan Disiplin Siswa. Pedagonal: Jurnal Ilmiah Pendidikan, 2(1), $\quad 1-14$. https://doi.org/10.33751/PEDAGOG.V2 I1.738

Nursalikah, A. (2021). Siswa Bengkulu Belajar di Tepi Sungai demi Sinyal Internet | Republika Online. https://www.republika.co.id/berita/qxe8 wt366/siswa-bengkulu-belajar-di-tepisungai-demi-sinyal-internet

Ramopoly, I. H., Tangkearung, S. S., \& Nisrawati, N. (2020). Pengaruh Bimbingan Orang Tua Terhadap Prestasi Belajar IPA Siswa Kelas IV SDN 116 Rante Kasimpo Kelas Jauh Kecamatan Makale Kabupaten Tana Toraja. Elementary Journal, 2(2), 1823.

http://journals.ukitoraja.ac.id/index.php/ ej/article/view/845

Ridlo, I. A. (2020). Pandemi COVID-19 dan Tantangan Kebijakan Kesehatan Mental di Indonesia. INSAN Jurnal Psikologi Dan Kesehatan Mental, 5(2), 162-171. https://doi.org/10.20473/JPKM.V5I2202 $0.162-171$
Sakti, B. P. (2020a). Peningkatan Hasil Belajar Pada Tema Karakteristik Geografis Indonesia Di Kelas V Sekolah Dasar Menggunakan Model Mind Mapping. Prima Magistra: Jurnal Ilmiah Kependidikan, $\quad 1(2), \quad 218-229$. https://doi.org/10.37478/jpm.v1i2.659

Sakti, B. P. (2020b). The Role Of Parents And Teachers In Supervising Primary School Student's Attitude Due To Influence From Technology Based On Industrial Revolution 4.0. Prosiding Seminar Nasional PBSI UPY, 1(1), 179-186. http://prosiding.pbsi.upy.ac.id/index.php /2019/article/view/26

Sakti, B. P. (2021a). Indikator Pemahaman EPortfolio Dalam Blended Learning Untuk Menghadapi Era Society 5.0. Prosiding PGSD UPY. https://doi.org/10.31219/OSF.IO/2Z58N

Sakti, B. P. (2021b). Persepsi Para Orang Tua Terhadap Pembelajaran Daring: Studi Pada Sebuah Sekolah Dasar Di Daerah Pinggiran Klaten. Prima Magistra: Jurnal Ilmiah Kependidikan, 2(1), 5865. https://doi.org/10.37478/JPM.V2I1.864

Sakti, B. P. (2021c). Tantangan Kebijakan Yang Dihadapi Guru Berkaitan Masa Pandemi. Seminar Nasional Teknologi Dan Multidisiplin Ilmu (SEMNASTEKMU), 1(1), 374-382. https://doi.org/10.51903/SEMNASTEK MU.V1I1.133

Sakti, B. P., \& Ayu, R. E. (2021). Online Learning Implementation at Public Elementary Schools in Urban Outskirts. Musamus Journal of Primary Education, 2021(2), 115-124. https://doi.org/10.35724/MUSJPE.V3I2. 3376

Septalisma, B. (2021). Survei: 10 Persen Orang RI Masih Tak Tahu Pakai Internet.

https://www.cnnindonesia.com/teknolog i/20201110171625-185-568208/survei10-persen-orang-ri-masih-tak-tahupakai-internet 
Taufiq, R. (2021). Orangtua di Malinau Keluhkan Semangat Siswa Menurun, Minta Penyesuaian Kurikulum Belajar Daring - Tribun Kaltim. https://kaltim.tribunnews.com/2021/08/0 7/orangtua-di-malinau-keluhkansemangat-siswa-menurun-mintapenyesuaian-kurikulum-belajar-daring

Utomo, M. A. D., Mutrofin, M., \& Alfarisi, R. (2021). Keefektifan Pembelajaran Daring untuk Pembelajaran Volume Bangun Ruang Kubus dan Balok. Jurnal Ilmu Pendidikan Sekolah Dasar.
https://jurnal.unej.ac.id/index.php/JIPSD /article/view/24731

Yulianto, D., \& Nugraheni, A. S. (2021). Efektivitas Pembelajaran Daring Dalam Pembelajaran Bahasa Indonesia. Decode: Jurnal Pendidikan Teknologi Informasi, 1(1), 33-42. https://doi.org/10.51454/DECODE.V1I1 .5 